\title{
UJI EFEKTIFITAS EKSTRAK BIJI KETUMBAR (Coriandrum sativum) SEBAGAI REPELLENT NYAMUK Aedes aegypti
}

Nurul Jubaedah, Winarko, Fitri Rohmalia

\begin{abstract}
ABSTRAK
Penyakit Demam Berdarah Dengue (DBD) di Surabaya semakin meningkat setiap tahunnya. Salah satu pencegahan untuk menurunkan kasus penyakit Demam Berdarah Dengue (DBD) dengan menggunakan repellent. Repellent dapat dibuat dari bahan alami yaitu ketumbar (Coriandrum sativum)yang di ekstrak. Ketumbar (Coriandrum sativum) memiliki kandungan linalool yang terkenal sebagai bahan yang dapat mencegah nyamuk Aedes aegypti untuk menggigit. Kandungan linalool pada ketumbar (Coriandrum sativum) sebesar $60-70 \%$. Tujuan penelitian ini yaitu untuk menganalisis efektifitas ekstrak biji ketumbar sebagai repellent terhadap nyamuk Aedes aegypti.

Jenis penelitian ini eksperimen murni dengan desain penelitian Rancangan Eksperimen Sederhana (posttest only with control group design). Kelompok perlakuan diberi perlakuan dengan dosis bertingkat. Terdapat 5 perlakuan repellent dari ekstrak ketumbar (Coriandrum sativum) terhadap nyamuk Aedes aegypti yaitu 0\%, 45\%, 50\%, $55 \%$, dan $60 \%$ dengan replikasi sebanyak 4 kali. Kondisi yang dikendalikan yaitu suhu, kelembaban dan karakteristik nyamuk. Teknik pengumpulan data diperoleh dari hasil observasi eksperimental dan wawancara. Data yang diperoleh selanjutnya dianalisis secara analitik menggunakan uji One way ANOVA dan menggunakan analisis probit.

Nyamuk Aedes aegypti yang kontak paling sedikit yaitu 1 ekor pada konsentrasi $60 \%$. Suhu dan kelembaban ruang penelitian homogen. Tidak ada perbedaan jumlah nyamuk kontak pada konsentrasi ekstrak biji ketumbar $0 \%, 45 \%, 50 \%, 55 \%$, dan $60 \%$. Konsentrasi yang paling efektif dari hasil probit yaitu konsentrasi $60 \%$ dengan daya tolak sebesar $98 \%$ dan daya proteksi lama waktu yang memenuhi standar WHO selama 2 jam. Saran untuk peneliti selanjutnya agar meningkatkan konsentrasi untuk mendapatkan daya proteksi $100 \%$. Penelitian terhadap jenis nyamuk yang lainnya seperti nyamuk Culex sp, Anopheles sp, Mansonia sp dan Aedes albopictus. Membuat repellent ekstrak biji ketumbar dalam bentuk krim atau gel.
\end{abstract}

Kata kunci : ekstrak ketumbar, nyamuk Aedes aegypti, dan repellent

\section{PENDAHULUAN}

Berdasarkan data WHO (2009) demam berdarah dengue banyak ditemukan di daerah tropis dan sub-tropis. Negara Indonesia sebagai negara dengan kasus DBD tertinggi di Asia Tenggara terbukti pada tahun 2007 Indonesia dilaporkan mendapatkan kasus Demam Berdarah Dengue (DBD) sebanyak 150.000 .

Demam Berdarah Dengue (DBD) disebabkan virus dengue yang termasuk kelompok B Arthropod Borne Virus (Arboviroses) yang sekarang dikenal sebagai genus flavivirus, famili flaviviridae, dan mempunyai 4 jenis serotipe, yaitu; DEN-1, DEN-2, DEN-3, DEN-4. (Depkes RI, 2011).

$$
\text { Berdasarkan pedoman }
$$

Kemenkes penggunaan Insektisida (pestisida) dalam pengendalian vektor (2012) menjelaskan yang dimaksud dengan repellent adalah bahan yang diaplikasikan lansung ke kulit, pakaian atau lainnya untuk mencegah kontak dengan serangga. Penggunaan bahan kimia contohnya DEET, etil-butilasetilamino prpionat dan ikaridin. Repellent dari bahan alam adalah minyak sereh/ sitronela (citronella oil) dan minyak eukaliptus/ lemon eucalyptus oil. Menurut Siregar (2011) Ketumbar mempunyai kandungan minyak atsiri berkisar antara 0,4-1,1\%, minyak ketumbar termasuk senyawa hidrokarbon beroksigen, komponen utama minyak ketumbar adalah linalool yang jumlah sekitar $60-70 \%$ dengan komponen pendukung yang lainnya adalah geraniol $(1,6-2,6 \%)$, geranil asetat $(2-3 \%)$, komfor $(2-4 \%)$ dan 
mengandung senyawa golongan hidrokarbon berjumlah sekitar $20 \%$ (apinen, $\beta$-pinen, dipenten, $p$-simen, $a-$ terpinen dan $\gamma$-terpinen, terpinolen dan fellendren.

Peneliti melakukan uji pendahuluan atau pra-eksperimen terhadap ekstrak biji ketumbar (Coriandrum sativum)sebagai repellent dengan konsentrasi $12,5 \%$, 25\%, $37,5 \%$, dan $50 \%$. Hasil uji pendahuluan atau pra eksperimen menunjukan bahwa ketumbar (Coriandrum sativum) konsentrasi yang berpotensi yaitu $50 \%$ dengan nyamuk Aedes aegypti betina yang hinggap sebanyak 1 ekor dari 50 ekor nyamuk Aedes aegypti betina.

Asliah (2015) melakukan penelitian mengenai repellent yang mengunakan tanaman zodia (Evodia suaveolens) konsentrasi yang paling efektif menghalau nyamuk adalah $12,5 \%$ dan $25 \%$ dengan kandungan linalool yang ada pada tanaman zodia sebesar $46 \%$. Berdasarkan uraian diatas peneliti tertarik untuk mengetahui serta melakukan lebih lanjut tentang "UJI EFEKTIVITAS EKSTRAK BIJI KETUMBAR (Coriandrum sativum) SEBAGAI
REPELLENT NYAMUK Aedes aegypti". Tujuan penelitian ini menganalisis efektivitas ekstrak biji ketumbar sebagai repellent terhadap nyamuk Aedes aegyti.

\section{METODE PENELITIAN}

Penelitian ini menggunakan desain penelitian Rancangan Eksperimen Sederhana (posttest only with control group design). Menggunakan jenis nyamuk Aedes aegypti betina usia 5-7 hari sebanyak 50 nyamuk perkandang. Pengulangan yang dilakukan sebanyak 6 kali mulai dari pukul 08.00-13.00 untuk mengetahui lama waktu perlindungan dan replikasi yang dilakukan sebanyak 4 repliksi.

\section{HASIL DAN PEMBAHASAN \\ Jumlah Nyamuk Aedes aegypti Yang Kontak Pada Tangan \\ Hasil pengujian ekstrak biji ketumbar (Coriandrum sativum) dengan konsentrasi $0 \%, 45 \%, 50 \%, 55 \%$, dan $60 \%$ terhadap jumlah nyamuk Aedes aegypti yang kontak pada tangan tersebut pada tabel 1 berikut ini.}

Tabel 1

RERATA JUMLAH NYAMUK YANG KONTAK PADA KONSENTRASI

$0 \%, 45 \%, 50 \%, 55 \%$, DAN $60 \%$

\begin{tabular}{|c|c|c|c|c|c|c|}
\hline \multirow{2}{*}{ Konsentrasi } & \multicolumn{4}{|c|}{$\begin{array}{c}\begin{array}{c}\text { Jumlah Nyamuk Yang } \\
\text { Kontak (Ekor) }\end{array} \\
\text { Replikasi } \\
\end{array}$} & \multirow{2}{*}{$\begin{array}{c}\text { Total } \\
\text { Nyamuk } \\
\text { Yang } \\
\text { Kontak } \\
\text { (Ekor) }\end{array}$} & \multirow{2}{*}{$\begin{array}{l}\text { Rerata } \\
\text { Yang } \\
\text { Kontak } \\
\text { (Ekor) }\end{array}$} \\
\hline & I & II & III & IV & & \\
\hline $0 \%$ & 36 & 39 & 34 & 36 & 145 & 36 \\
\hline $45 \%$ & 4 & 3 & 3 & 1 & 11 & 3 \\
\hline $50 \%$ & 3 & 2 & 2 & 1 & 8 & 2 \\
\hline $55 \%$ & 3 & 2 & 1 & 1 & 7 & 2 \\
\hline $60 \%$ & 1 & 2 & 1 & 0 & 4 & 1 \\
\hline
\end{tabular}


Berdasarkan hasil penelitian jumlah nyamuk yang kontak pada tangan lebih banyak pada konsentrasi kontrol dan jumlah nyamuk kontak pada perlakuan yang diberi larutan ekstrak biji ketumbar dengan konsentrasi $45 \%$, 50\%, 55\%, $60 \%$ paling sedikit yaitu pada konsentrasi $60 \%$. Hal itu dikarenakan lengan yang menjadi kontrol tidak diberi ekstrak biji ketumbar sedangkan lengan yang diberikan perlakuan telah diberi larutan ekstrak biji ketumbar yang mengandung senyawa linalool.

Linalool mempunyai aroma wangi yang diduga nyamuk tidak menyukai. Dalam kandungan linalool juga terdapat kandungan geraniol. Geraniol merupakan bahan aktif yang tidak disukai dan sangat dihindari serangga, termasuk nyamuk sehingga penggunaan bahan-bahan ini sangat bermanfaat sebagai bahan pengusir nyamuk (Kardinan, 2005).

Tabel 2

HASIL PERHITUNGAN DAYA PROTEKSI EKSTRAK BIJI KETUMBAR TERHADAP NYAMUK AEDES AEGYPTI

\begin{tabular}{|c|c|c|c|c|c|}
\hline \multirow{3}{*}{ Konsentrasi } & \multirow{2}{*}{\multicolumn{4}{|c|}{$\begin{array}{c}\text { Prosentase Daya Proteksi (\%) } \\
\text { Replikasi }\end{array}$}} & \multirow{3}{*}{$\begin{array}{c}\text { Rerata } \\
\text { Prosentase Daya } \\
\text { Proteksi (\%) }\end{array}$} \\
\hline & & & & & \\
\hline & I & II & III & IV & \\
\hline $0 \%$ & $0 \%$ & $0 \%$ & $0 \%$ & $0 \%$ & $0 \%$ \\
\hline $45 \%$ & $89 \%$ & $92 \%$ & $92 \%$ & $97 \%$ & $92 \%$ \\
\hline $50 \%$ & $92 \%$ & $94 \%$ & $94 \%$ & $97 \%$ & $95 \%$ \\
\hline $55 \%$ & $92 \%$ & $94 \%$ & $97 \%$ & $97 \%$ & $96 \%$ \\
\hline $60 \%$ & $97 \%$ & $94 \%$ & $97 \%$ & $100 \%$ & $97 \%$ \\
\hline
\end{tabular}

Hasil prosentase daya proteksi didapatkan dengan rumus daya proteksi yaitu: Daya Proteksi $=\frac{\Sigma C-\Sigma T}{\Sigma C}$ X $100 \%$

Keterangan :

$\mathrm{C}=$ Jumlah nyamuk yang kontak pada lengan kontrol

$\mathrm{T}=$ Jumlah nyamuk yang kontak pada lengan perlakuan.

Pada hasil daya proteksi penelitian ini yang paling tinggi yaitu konsentrasi $60 \%$ dengan pencapaian daya proteksi $97 \%$.

\section{Analisis Perbedaan Suhu Dan Kelembaban Ruang Penelitian Pada Pengujian Repellent Nyamuk Aedes aegypti}

Hasil rerata pengukuran suhu ruang penelitian selama pengujian dilakukan sebagai berikut :

Tabel 3

RERATA HASIL SUHU RUANG PENELITIAN

\begin{tabular}{|c|c|c|c|c|c|c|}
\hline \multirow{3}{*}{$\mathbf{R}$} & \multicolumn{5}{|c|}{ Suhu Ruang Penelitian $\left({ }^{\circ} \mathrm{C}\right)$} & \multirow{3}{*}{$\begin{array}{c}\text { Kisaran Suhu } \\
\text { Ruang Penelitian } \\
\left({ }^{\circ} \mathrm{C}\right)\end{array}$} \\
\hline & \multicolumn{5}{|c|}{ Replikasi } & \\
\hline & $0 \%$ & $45 \%$ & $50 \%$ & $55 \%$ & $60 \%$ & \\
\hline I & 26,8 & 26,5 & 26,8 & 25,8 & 26,9 & $25,8-26,9$ \\
\hline II & 26,4 & 26,8 & 26 & 26,5 & 26,7 & $26-26,8$ \\
\hline III & 26,3 & 26,6 & 26,5 & 26,7 & 26,4 & $26,3-26,7$ \\
\hline IV & 26,7 & 26,8 & 26,5 & 26,7 & 26,7 & $26,5-26,8$ \\
\hline Rerata & 26,6 & 26,7 & 26,5 & 26,4 & 26,7 & $26,4-26,7$ \\
\hline
\end{tabular}


Rerata suhu udara diruang penelitian selama 6 jam berkisar antara $26,4^{\circ} \mathrm{C}-26,7^{\circ} \mathrm{C}$ dan rerata suhu udara di ruang penelitian dari kelima konsentrasi adalah $26,6{ }^{\circ} \mathrm{C}$. Suhu rata-rata optimum untuk perkembangan nyamuk adalah $25^{\circ} \mathrm{C}-27^{\circ} \mathrm{C}$ (Dani, 2011).

Hasil analisis perbedaan suhu ruang penelitian pada uji One way anova keseluruhan dari kelima konsentrasi yaitu $0 \%, 45 \%, 50 \%, 55 \%$, dan $60 \%$ didapatkan hasil nilai signifikansi 0,613 . Nilai signifikansi atau $p=0,613$ maka $p>0,05$ yang berarti tidak ada perbedaan suhu ruang penelitian pada pengujian repellent nyamuk Aedes aegypti menggunakan ekstrak biji ketumbar dengan konsentrasi $0 \%, 45 \%, 50 \%, 55 \%$, dan $60 \%$. Ruang penelitian menggunakan pendingin ruangan sehingga Suhu ruang penelitian hasilnya homogen sehingga tidak mempengaruhi jumlah nyamuk yang kontak pada konsentrasi $0 \%, 45 \%$, $50 \%, 55 \%$, dan $60 \%$.

Hasil rata-rata pengukuran kelembaban ruang penelitian selama pengujian dilakukan sebagai berikut :

Tabel 4

RERATA HASIL KELEMBABAN RUANG PENELITIAN

\begin{tabular}{|c|c|c|c|c|c|c|}
\hline & \multicolumn{5}{|c|}{ Kelembaban ruang penelitian (\%) } & \multirow{3}{*}{$\begin{array}{c}\text { Kisaran } \\
\text { Kelembaban } \\
\text { Ruang } \\
\text { Penelitian (\%) }\end{array}$} \\
\hline & \multicolumn{5}{|c|}{ Replikasi } & \\
\hline & $0 \%$ & $45 \%$ & $50 \%$ & $55 \%$ & $60 \%$ & \\
\hline $\mathbf{I}$ & 67 & 66 & 69 & 70 & 70 & $66-70$ \\
\hline II & 68 & 67 & 68 & 67 & 67 & $67-68$ \\
\hline III & 69 & 68 & 65 & 68 & 66 & $65-68$ \\
\hline IV & 67 & 66 & 66 & 67 & 68 & $66-68$ \\
\hline Rerata & 68 & 67 & 67 & 68 & 68 & $67-68$ \\
\hline
\end{tabular}

Rerata kelima konsentrasi $=\mathbf{6 8 \%}$

diruang penelitian selama 6 jam berkisar antara $67 \%-68 \%$ dan rata-rata kelembaban udara diruang penelitian adalah $68 \%$. kelembaban yang disarankan $\geq 80 \pm 10 \%$ (WHO, 2009). Hasil analisis perbedaan kelembaban ruang penelitian pada uji One way anova keseluruhan dari kelima konsentrasi yaitu $0 \%, 45 \%, 50 \%, 55 \%$, dan $60 \%$ didapatkan hasil nilai signifikansi 0,680 . Nilai signifikansi atau $\mathrm{p}=0,680$ maka $\mathrm{p}>0,05$ yang berarti tidak ada perbedaan kelembaban ruang penelitian pada pengujian repellent nyamuk Aedes aegypti menggunakan ekstrak biji ketumbar dengan konsentrasi $0 \%, 45 \%$, $50 \%$, 55\%, dan $60 \%$.

Kelembaban tidak ada perbedaan karena pada ruang penelitian digunakan pendingin ruangan sehingga kelambaban pada ruangan tetap terjaga sehinggal hasil dari pengukuran kelembaban homogen dari awal penelitian sampai penelitian selesai. 


\section{Konsentrasi Ekstrak Biji Ketumbar Yang Paling Efektif Sebagai Repellent Nyamuk Aedes aegypti $\left(E^{50}\right)$}

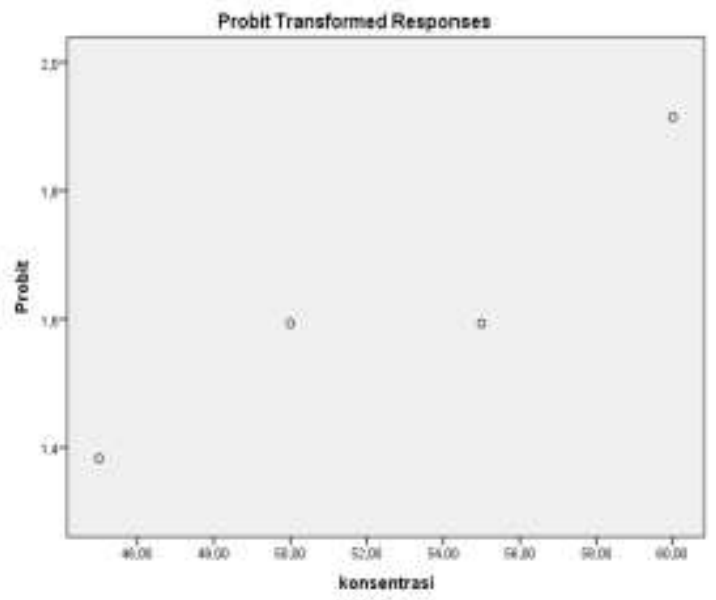

Gambar V. 1

Grafik Probit Transformed Responses

Hasil pada grafik diatas menunjukan kenaikan disetiap konsentrasi maka dapat disimpulkan bahwa grafik berdistribusi normal. Effective doses yang dicari yaitu effective doses yang dapat mengusir atau menolak nyamuk sebesar $50 \%$ $\left(E D_{50}\right)$. Hasil dari analisis probit didapatkan $\mathrm{ED}_{50}$ dengan rata-rata yaitu $12,691 \%$. Pada hasil probit konsentrasi yang paling efektif dari konsentrasi $45 \%$, 50\%, 55\%, dan $60 \%$ yaitu konsentrasi $60 \%$ dengan daya tolak sebesar $98 \%$.

Analisis Perbedaan Jumlah Nyamuk Aedes aegypti Yang Kontak Hasil uji perbedaan One way
keseluruhan dari kelima konsentrasi yaitu $0 \%, 45 \%, 50 \%, 55 \%$, dan $60 \%$ didapatkan nilai signifikansi atau $\mathrm{P}=0,000$ maka $\mathrm{P}<0,05$ yang berarti ada perbedaan. Jadi, Ho ditolak yang berarti ada perbedaan nyamuk Aedes aegypti yang kontak pada tangan dengan konsentrasi ekstrak biji ketumbar dengan konsentrasi $0 \%, 45 \%$, $50 \%$, $55 \%$ dan $60 \%$.

\section{Lama Waktu Perlindungan Ekstrak Biji Ketumbar (Coriandrum sativum) Sebagai Repellent Nyamuk Aedes aegypti}

Hasil jumlah nyamuk Aedes aegypti yang kontak pada pengukuran lama waktu perlindungan ekstrak biji ketumbar sebagai berikut:

Tabel 5

RERATA JUMLAH NYAMUK AEDES AEGYPTIYANG KONTAK PADA PENGUKURAN LAMA WAKTU PERLINDUNGAN EKSTRAK BIJI KETUMBAR

\begin{tabular}{|c|c|c|c|c|c|c|c|c|}
\hline \multirow{3}{*}{ Konsentrasi } & \multirow{2}{*}{\multicolumn{6}{|c|}{$\begin{array}{c}\text { Jumlah Nyamuk Yang Kontak (Ekor) } \\
\text { Waktu/ Jam ke- }\end{array}$}} & \multirow{3}{*}{$\begin{array}{c}\text { Total } \\
\text { Nyamuk } \\
\text { Yang } \\
\text { Kontak } \\
\text { (Ekor) }\end{array}$} & \multirow{3}{*}{$\begin{array}{c}\text { Rerata } \\
\text { Nyamuk } \\
\text { Yang } \\
\text { Kontak } \\
\text { (Ekor) }\end{array}$} \\
\hline & & & & & & & & \\
\hline & $\mathbf{I}$ & II & III & IV & $\mathbf{v}$ & VI & & \\
\hline $0 \%$ & 36 & 33 & 32 & 30 & 28 & 27 & 186 & 31 \\
\hline $45 \%$ & 3 & 4 & 5 & 6 & 8 & 9 & 35 & 6 \\
\hline $50 \%$ & 2 & 2 & 4 & 5 & 7 & 8 & 28 & 5 \\
\hline $55 \%$ & 2 & 2 & 4 & 4 & 6 & 7 & 25 & 4 \\
\hline $60 \%$ & 1 & 1 & 2 & 3 & 4 & 5 & 16 & 3 \\
\hline
\end{tabular}


Jumlah nyamuk yang kontak paling sedikit di setiap jam pengukurannya yaitu konsentrasi $60 \%$ dengan jumlah nyamuk yang kontak jam pertama dan kedua 1 ekor, jam ketiga 2 ekor, jam keempat 3 ekor, jam ke lima 4 ekor dan jam keenam 5 ekor. Hasil perhitungan daya proteksi ekstrak biji ketumbar sebagai berikut:

Tabel 6

HASIL PERHITUNGAN DAYA PROTEKSI EKSTRAK BIJI KETUMBAR TERHADAP NYAMUK AEDES AEGYPTI

\begin{tabular}{|c|c|c|c|c|c|c|c|c|}
\hline \multirow{3}{*}{$\mathbf{K}$} & \multirow{2}{*}{\multicolumn{6}{|c|}{$\begin{array}{c}\text { Daya Proteksi (\%) } \\
\text { Waktu/ Jam ke- }\end{array}$}} & \multirow{3}{*}{$\begin{array}{c}\text { Kisaran } \\
\text { Daya } \\
\text { Proteksi } \\
(\%)\end{array}$} & \multirow{3}{*}{$\begin{array}{c}\text { Rerata } \\
\text { Daya } \\
\text { Proteks } \\
(\%)\end{array}$} \\
\hline & & & & & & & & \\
\hline & I & II & III & IV & $\mathbf{v}$ & VI & & \\
\hline $0 \%$ & $0 \%$ & $0 \%$ & $0 \%$ & $0 \%$ & $0 \%$ & $0 \%$ & $0 \%$ & $0 \%$ \\
\hline $45 \%$ & $92 \%$ & $88 \%$ & $84 \%$ & $80 \%$ & $71 \%$ & $67 \%$ & $67 \%-92 \%$ & $80 \%$ \\
\hline $50 \%$ & $94 \%$ & $94 \%$ & $88 \%$ & $83 \%$ & $75 \%$ & $70 \%$ & $70 \%-94 \%$ & $84 \%$ \\
\hline $55 \%$ & $94 \%$ & $94 \%$ & $88 \%$ & $88 \%$ & $79 \%$ & $74 \%$ & $74 \%-94 \%$ & $86 \%$ \\
\hline $60 \%$ & $97 \%$ & $97 \%$ & $94 \%$ & $90 \%$ & $86 \%$ & $82 \%$ & $82 \%-97 \%$ & $91 \%$ \\
\hline \multicolumn{9}{|c|}{$\mathrm{K}=$ Konsentrasi } \\
\hline
\end{tabular}

Daya proteksi yang paling tinggi pada konsentrasi konsentrasi $60 \%$ pada jam pertama dan kedua $97 \%$, jam ketiga $94 \%$, jam keempat $90 \%$, jam kelima $86 \%$, jam keenam $82 \%$ dan kisaran daya proteksi $82 \%-97 \%$ dengan rerata $91 \%$.

$$
\text { Berdasarkan WHO (2009) }
$$
standar daya proteksi yang dapat dijadikan repellent yaitu $95 \%$. Hasil dari penelitian ini konsentrasi yang memenuhi standar WHO daya proteksi yaitu pada konsentrasi $60 \%$ pada jam pertama dan kedua dengan daya proteksi $97 \%$. Pada konsentrasi lainnya belum memenuhi standar WHO tahun 2009 karena daya proteksi kurang dari $95 \%$. Faktor yang mempengaruhi konsentrasi $60 \%$ bertahan selama 2 jam karena kandungan linalool pada konsentrasi $60 \%$ lebih banyak dari pada konsentrasi $45 \%$, 50\%, dan 55\%. Repellent mempunyai cara kerja dalam menghalau nyamuk untuk kontak atau hinggap yaitu dengan merancukan indra penciumannya terhadap mangsanya. Minyak atsiri mempunyai sifat yang menguap, maka penurunan dalam kemampuan repellent disebabkan karena terjadinya penguapan.
Kenaikan jumlah nyamuk yang kontak dan penurunan daya proteksi disebabkan karena adanya penguapan bahan aktif pada ekstrak biji ketumbar, kegiatan suka relawan setiap jamnya, dan keringat sukarelawan yang di keluarkan tubuhnya. Minyak atsiri bersifat mudah menguap karena titik uapnya rendah. Susunan senyawa komponennya kuat mempengaruhi saraf manusia (terutama di hidung) sehingga memberikan efek psikologis tertentu (baunya kuat). Minyak atsiri mempunyai rasa getir (pungent taste), berbau wangi sesuai dengan bau tanaman penghasilnya dan umumnya larut dalam pelarut organik tetapi tidak dalam air (Daniel, 2012).

\section{KESEIMPULAN DAN SARAN Kesimpulan}

Bedasarkan hasil penelitian dapat disimpulkan sebagai berikut:

1. Jumlah rerata nyamuk yang kontak paling sedikit pada konsentrasi $60 \%$ sebanyak 1 ekor dengan daya proteksi $97 \%$ dan yang paling banyak jumlah rerata nyamuk yang kontak pada konsentrasi $0 \%$ atau kontrol sebanyak 36 ekor dengan daya proteksi $0 \%$. 
2. Hasil analisis perbedaan suhu didapatkan nilai $p=0,613$ maka $p$ $>0,05$ dan hasil analisis perbedaan kelembaban didapatkan nilai $\mathrm{p}=$ 0,680 maka $p>0,05$ yang berarti tidak ada perbedaan suhu dan kelembaban ruang penelitian pada pengujian repellent nyamuk Aedes aegypti menggunakan ekstrak biji ketumbar dengan konsentrasi $0 \%$, $45 \%, 50 \%$, 55\%, dan $60 \%$ maka disumpulkan bahwa suhu dan kelembaban tidak ada pengaruh terhadap nyamuk yang kontak.

3. Hasil $\mathrm{ED}_{50}$ didapatkan konsentrasi $12,691 \%$ dapat menolak nyamuk Aedes aegypti sebesar $50 \%$ dan konsentrasi yang paling efektif dari konsentrasi $45 \%$, 50\%, 55\%, dan $60 \%$ dilihat dari hasil probit yaitu konsentrasi $60 \%$ dengan daya tolak sebesar $98 \%$.

4. Hasil uji perbedaan One way anova keseluruhan dari kelima konsentrasi yaitu $0 \%, 45 \%, 50 \%$, 55\%, dan $60 \%$ didapatkan nilai signifikansi atau $\mathrm{P}=0,000$ maka $\mathrm{P}<0,05$ yang berarti ada perbedaan nyamuk Aedes aegypti yang kontak pada tangan dengan konsentrasi ekstrak biji ketumbar dengan konsentrasi $0 \%, 45 \%, 50 \%$, 55\% dan $60 \%$.

5. Daya proteksi lama waktu yang memenuhi standar WHO tahun 2009 yaitu pada konsentrasi $60 \%$ dengan lama perlindungan selama 2 jam.

\section{Saran}

1. Mengembangkan penelitian ini sebagai pengendalian nyamuk alami yang dapat direkomendasikan kepada masyarakat dan berkerjasama dengan instansi kesehatan untuk mengembangkan penelitian ini lebih lanjut.

2. Perlu adanya peningkatan konsentrasi untuk mendapatkan daya proteksi $100 \%$.

3. Perlu adanya penelitian lebih lanjut terhadap jenis nyamuk yang lainnya seperti nyamuk Culex $s p$, Anopheles $s p$, Mansonia $s p$ dan Aedes albopictus.
4. Sebaiknya peneliti melakukan pemeriksaan besar konsentrasi bahan aktif yang terkandung dalam ekstrak biji ketumbar (Coriandrum sativum) beserta karakteristik zat tersebut.

5. perlu adanya penelitian lebih lanjut membuat repellent ekstrak biji ketumbar dalam bentuk krim atau gel.

\section{DAFTAR PUSTAKA}

Asliah, S., 2015. Efektivitas Ekstrak Tanaman Zodia Evodia suaveolens Pada Berbagai Konsentrasi Repellent Terhadap Aktivitas Menghisap Darah Nyamuk Aedes aegypti. Universitas Hasanuddin. http://repository.unhas.ac.id/hand le/123456789/14108. Diakses pada hari selasa, 10 Januari 2017.

Daniel, A., 2012. Prospek bertanam Nilam wangi. Yogyakarta, Pustaka Baru Press.

Dani, C., 2011. Vektor Penyakit Tropis. Yogyakarta, Gosyen Publishing.

Departemen Kesehatan Republik Indonesia, 2011. TataLaksana DBD. Jakarta, Kemenkes RI.

Kardinan, A., 2005. Tanaman Penghasil Minyak Atsiri. Depok, PT. Agro Media Pustaka.

Kementerian Kesehatan Republik Indonesia, 2012. Pedoman Penggunaan Insektisida (Pestisida) Dalam Pengendalian Vektor. Jakarta, Kemenkes RI.

Siregar, A., Putri, A., Purwadianto, A.,

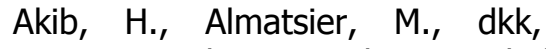
2011. Formularium Obat Herbal Asli Indonesia. Jakarta, Kemenkes RI. Hal. 91-93

World Health Organization, 2009. Guidelines For Efficacy Testing of Mosquito Repellents For Human Skin. 